\title{
THE USE OF GENERATING SETS WITH ING GAS ENGINES IN "SHORE TO SHIP" SYSTEMS
}

\author{
Dariusz TARNAPOWICZ \\ Maritime University of Szczecin \\ Sergiej GERMAN-GALKIN \\ University ITMO, Sankt Petersburg
}

\begin{abstract}
:
The main sources of air pollution in ports are ships, on which electrical energy is produced in the autonomous generating sets Diesel-Generator. The most effective way to reduce harmful exhaust emissions from ships is to exclude marine generating sets and provide the shore-side electricity in "Shore to Ship" system. The main problem in the implementation of power supply for ships from land is connected with matching parameters of voltage in onshore network with marine network. Currently, the recommended solution is to supply ships from the onshore electricity network with the use of power electronic converters. This article presents an analysis of the "Shore to Ship" system with the use of generating sets with LNG gas engines. It shows topologies with LNG - Generator sets, environmental benefits of such a solution, advantages and disadvantages.
\end{abstract}

Key words: „Shore To Ship" system, LNG generating sets

\section{INTRODUCTION}

Maritime transport plays an important role in the global economy. Constantly increasing state of the world transport fleet causes an increase in the number of ships berthing in ports. An increasing share of mechatronic systems and advanced automation system on ships leads to the growth in demand for electricity. Sources of electricity on ships are autonomous generating sets Diesel-Generator (D-G). During a standstill at the port, ships are a source of air pollution. Researches about the exhaust emission, which are carried out in ports, lead to the conclusion that nitrogen oxides $\left(\mathrm{NO}_{\mathrm{x}}\right)$, carbon dioxide $\left(\mathrm{CO}_{2}\right)$ and sulfur oxide (SOx) are mainly generated by marine vessels $[1,2]$.

Marine D-G generating sets working in ports are also a source of noise at the level of an average acoustic power above $100 \mathrm{~dB}$. The level of noise generated by motors in aggregates with a power over 1 MVA reaches up to $140 \mathrm{~dB}$. Furthermore, generating sets emit vibrations exceeding the threshold of human sensitivity.

In the last two decades, IMO (International Maritime Organization) has developed a set of regulations on the prevention of air pollution from ships, which concern two ingredients of harmful exhaust fumes $\mathrm{NO}_{\mathrm{x}}$ and $\mathrm{SO}_{\mathrm{x}}$. Limitation in emission of these exhaust components must be enforced especially in special ECA zones (Emission Control Area). An example for the reduction of $\mathrm{SO}_{x}$ emission can be the use of more and more popular fuels with low sulfur content in ships.

The only effective method of reducing exhaust emission (all components), as well as limitation of noise and vibrations in ports is to disable the autonomous DG power gen- erators and connect ships to the electricity network on land.

The main problem of connecting a ship in the port to the electricity network on land is associated with the adjustment of both electrical networks. The rating of voltages in marine networks varies depending on the class of ships, their size and area of exploitation. Marine vessels are characterized by approx. 10 levels of low voltages (less than $1000 \mathrm{~V}$ ) and 3 levels of medium voltages (3.3 kV, $6.6 \mathrm{kV}$ and $11 \mathrm{kV})$. Different frequency of voltage in the ship network in relation to the land-based network is also important. Ships usually have the frequency of the mains voltage at the level of $60 \mathrm{~Hz}$ (approx. 70\% of ships) [1]. In the world, the popular frequency of energy networks is $50 \mathrm{~Hz}$ (Europe, Asia, Africa, South America). Differing levels of voltages in land and marine network are not a technical problem. Technologically advanced power transformers, which costs are not high, allow adjusting the level of voltages. A bigger problem is to match the frequency of voltages. Recommended and practically the only current solution is the use of frequency converters $[3,4]$. An alternative for frequency converters can be the use of generating sets with LNG gas engines.

Construction of the universal "Shore to Ship" (STS) system, allowing electrical connection of each ship in the port, is connected with the global standardization of the system. In July 2012, IEC/ISO/IEEE 80005-1 was published [4]. The purpose of this standard is to define requirements, support for designers, determine an appropriate practice of connection, ensure rapid operability when connecting and secure the safety of connection carried out by the crew of ships and port workers. 


\section{LNG GENERATING SETS - GENERATOR IN STS SYSTEM}

An alternative solution for obtaining a voltage with a frequency of $60 \mathrm{~Hz}$ can be a generating set, in which a gas engine utilizing LNG (Liquefied Natural Gas).

LNG method consists in the liquefaction of natural gas, thus reducing its volume by approx. 600 times. The condensation temperature of methane is $-161.6^{\circ} \mathrm{C}$. This means that from $1 \mathrm{~m}^{3}$ of liquefied gas, we can get $584 \mathrm{~m}^{3}$ of network gas, while from 1 ton of LNG - approx. $1380 \mathrm{~m}^{3}$ of gas.

Until recently it was believed that D-G generating sets are highly reliable and inexpensive, but they are loud and emit toxic compounds into the atmosphere, while LNG generating sets - (LNG-G) Generator - are expensive and less powerful, but more quiet and with a low emission of air pollutants. Currently, thanks to the development of new technologies in engines, housings and other elements, the differences concerning available powers are already comparable. When it comes to durability, diesel engines are still more durable in comparison with LNG engines.

However, new technologies can increase efficiency of LNG engines and simultaneously raising their reliability and durability. Worldwide sales of generating sets currently amounts to $82 \%$ of D-G and $12 \%$ of LNG-G, but forecasts say that this ratio will be leveled in the coming 10 years [5].

There are many companies offering LNG-G generating sets, but only few of them are leaders on the market (Caterpillar, Cummins, Perkins, MAN or MWM-Deutz). For the STS system, analyzing the possibilities of use, and most of all available powers of LNG-G gene-rating sets, Caterpillar has the broadest offer. Figure 1 presents generators sets from Caterpillar (types: CG170-16 and CG260-16). The analysis of these sets concerning their use in STS system will be showed in the later part of the paper.

Selected technical data of LNG-G generating sets [6]:

- CG170-16 - P = $1550 \mathrm{~kW}$; U = $11 \mathrm{kV}, \mathrm{f}=60 \mathrm{~Hz}$; fuel Natural Gas,

- CG260-16 - P = $4000 \mathrm{~kW}$; U = $11 \mathrm{kV}, \mathrm{f}=60 \mathrm{~Hz}$; fuel Natural Gas.

Solution with the use of LNG-G generating set requires, in addition to a complicated installation supplying the generating set, LNG tanks for gas storage. As already mentioned, $1 \mathrm{~m}^{3}$ of LNG is equal to $600 \mathrm{Nm}^{3}$ (cubic meters at standard conditions) of natural gas, which allows its storage by the concentration of a large amount of energy in a small volume. Tanks with a capacity of $60 \mathrm{~m}^{3}$ are the most often produced tanks. This value corresponds to $36000 \mathrm{Nm}^{3}$. Such a tank, assuming the electricity consumption of $1 \mathrm{MW}$ per day, is enough for about 5 days.

In addition to the tank, LNG installation also includes air vaporizers, gas preheaters, reduction lines and automation control system. This installation requires additional space in the port. Fig. 2 shows an exemplary flowchart of LNG regasification facilities. a)

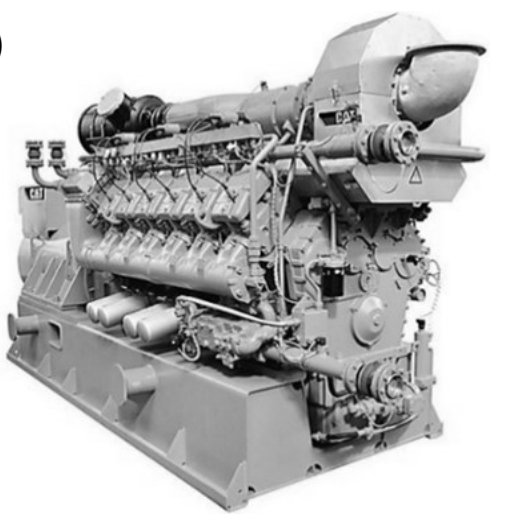

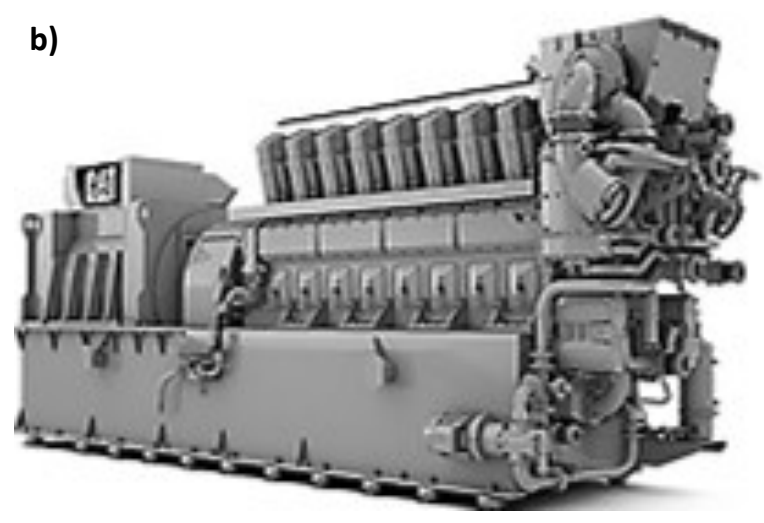

Fig. 1 Generators sets from Caterpillar:

a) CG170-16 with a power of $1550 \mathrm{~kW}$ b) CG260-16 with a power of $4000 \mathrm{~kW}$

Source: [6].

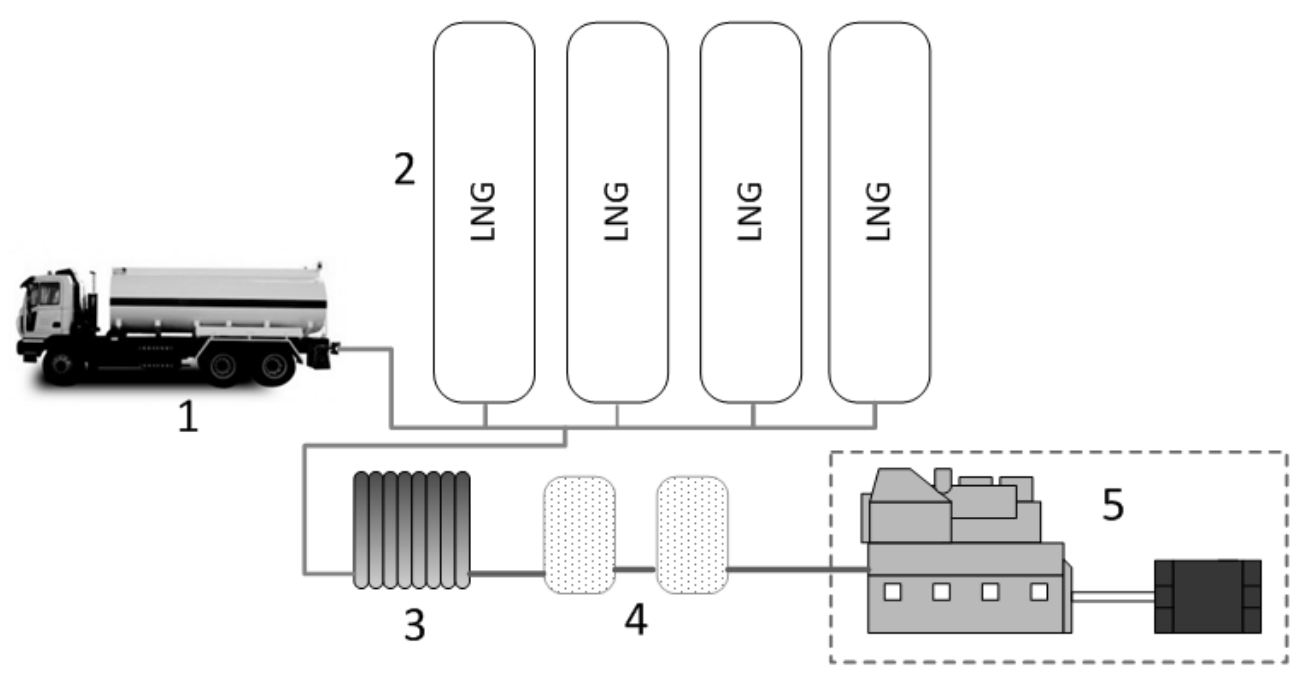

Fig. 2 Flowchart of LNG regasification facilities to power $L N-G$ generating sets 
The main elements of such a system include [7]:

1. Cryogenic cistern- LNG gas is transported to the regasification station in specialized cryogenic cisterns, which maintain low temperature of liquefied gas during the transportation. A typical cistern has a capacity of 18 tons, of which we can get $256000 \mathrm{~m}^{3}$ of fuel in gaseous form after regasification.

2. Cryogenic tanks - technologically, there is a possibility of adding extra tanks at the LNG regasification station in order to obtain a greater storage capacity.

3. Vaporizers - vaporizers used to change the gas fuel from liquid to gaseous form. They are designed to provide the power of regasification, which is required by the recipient (calculated in $\mathrm{m}^{3} / \mathrm{h}$ ).

4. Reduction and measuring station - it carried out the measurement of gas fuel and reduction of gas pressure. Pressure reduction can be made at the station or in the gas path in front of the receiver. The final decision is made by the installation designer individually for each project.

5. LNG-G generating set room.

An analysis of reducing exhaust emission with the use of STS system was carried out in order to compare the work of marine generating sets while supplying with Heavy FuelOil (HFO) and Marine Diesel Oil (MDO) for the production of $1 \mathrm{MWh}$ of electricity through the entire year in relation to the STS system powered by LNG-G generating sets and power grid (Coal Power Station).

Reduction in the exhaust emission by the use of the above-mentioned solutions was summarized in Table 1 for different sources of energy that produce energy in the amount of $1 \mathrm{MWh}$ throughout the year.

Percentage profit in the reduction of exhaust emission from the use of STS system is shown in Table 2.

The performed analysis leads to the conclusion that the reduction of exhaust emission by ships in the port with the use of STS system is comparable with the use of LNG-G and power supply from Coal Power Station. Only by using the STS system powered from the power grid, a level of $\mathrm{CO}_{2}$ emission increases. This has no direct impact on the health of local residents, because Coal Power Station is usually located far from the city.

\section{TYPOLOGY OF STS SYSTEM WITH THE USE OF LNG-G GEN- ERATING SETS}

In order to select the optimal topology of the system, it is necessary first to carry out the analysis of power requirements and parameters of marine electrical networks in terms of voltage frequency for ships using the STS system.

The exemplary analysis was carried out for the power demand on the waterfront - $7 \mathrm{MW}$ - and the number of ships with a voltage frequency for marine network $60 \mathrm{~Hz}$ at the level of $65 \%$. For a minimum interference in the port's waterfront, main stations with LNG-G generating sets and power transformers are located far from wharfs. Only automated davits with cabling and connectors are installed on a wharf [1]. Two variants of STS system's topology were taken into account.

\section{Topology}

I topology is presented in Fig. 3.

In the main station, there is a high power ( $4 \mathrm{MW}$ ) autonomous LNG-G generating set realizing a voltage source of $11 \mathrm{kV}$ with frequency of $60 \mathrm{~Hz}$ and a power transformer with a power of $3 \mathrm{MW}$ and secondary voltage of $11 \mathrm{kV}$ ensuring electrical energy source with a frequency of $50 \mathrm{~Hz}$. Two power supply lines $50 \mathrm{~Hz}$ and $60 \mathrm{~Hz}$ are located between the main station (placed away from the wharf) and a place for the placement of ferries on individual quays. This is an advantage of the system because of the small amount of cables. The disadvantage of this solution is that in case of failure of LNG-G generating set that supply several ships, there will be a break in their supply.

Moreover, the ability to work for an unloaded gas engine in LNG-G generating set is important. In the case of supply for only one ship, LNG-G generating set can work at the value of about $30 \%$ of the nominal power. It is associated with an increased amount of gas needed to produce 1 MWh of electricity. Fig. 4 shows the relation in gas consumption for Caterpillar CG260-16 set (with a power of 4 $\mathrm{MW})$.

Table 1

Exhaust emission in the port from various sources

Emissions (ton/year)

\begin{tabular}{ccccc}
\cline { 2 - 4 } Pollutants & \multicolumn{2}{c}{ Ship generating set } & \multicolumn{2}{c}{ STS } \\
$\mathrm{CO}_{2}$ & MDO - Generator & HFO -Generator & Coal Power Station & LNG-Generator \\
$\mathrm{NO}_{x}$ & 4111.36 & 4111.36 & 7901.52 & 3521.52 \\
$\mathrm{PM}$ & 87.3664 & 87.3664 & 3.564 & 3.095669 \\
$\mathrm{SO}_{2}$ & 2.69808 & 4.034272 & 0.028539 & 0 \\
\hline
\end{tabular}

Source: based on [8].

Table 2

Percentage profit in the reduction of exhaust emission from the use of STS system

\begin{tabular}{ccc}
\hline \multirow{2}{*}{ Pollutants } & \multicolumn{2}{c}{ Emission reductions electricity by STS } \\
\cline { 2 - 3 } $\mathrm{NO}_{\mathrm{x}}$ & Coal Power Station & LNG-Generator \\
$\mathrm{PM}$ & $96 \%$ & $96 \%$ \\
$\mathrm{SO}_{2}$ & $95 \%$ & $100 \%$ \\
$\mathrm{CO}_{2}$ & $99 \%$ & $100 \%$ \\
\hline
\end{tabular}




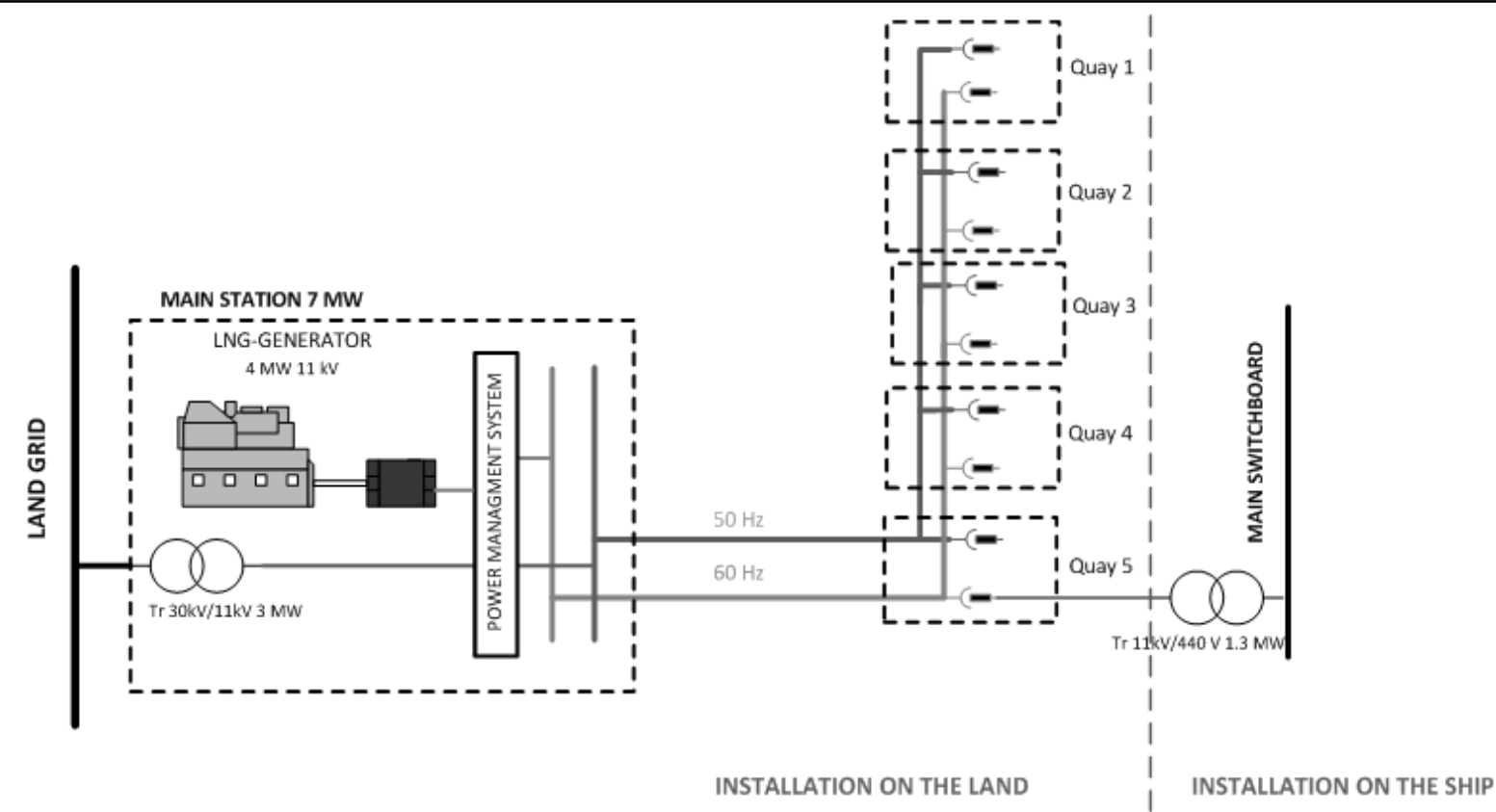

Fig. 3 Typology of STS system with the use of LNG-G 4 MW

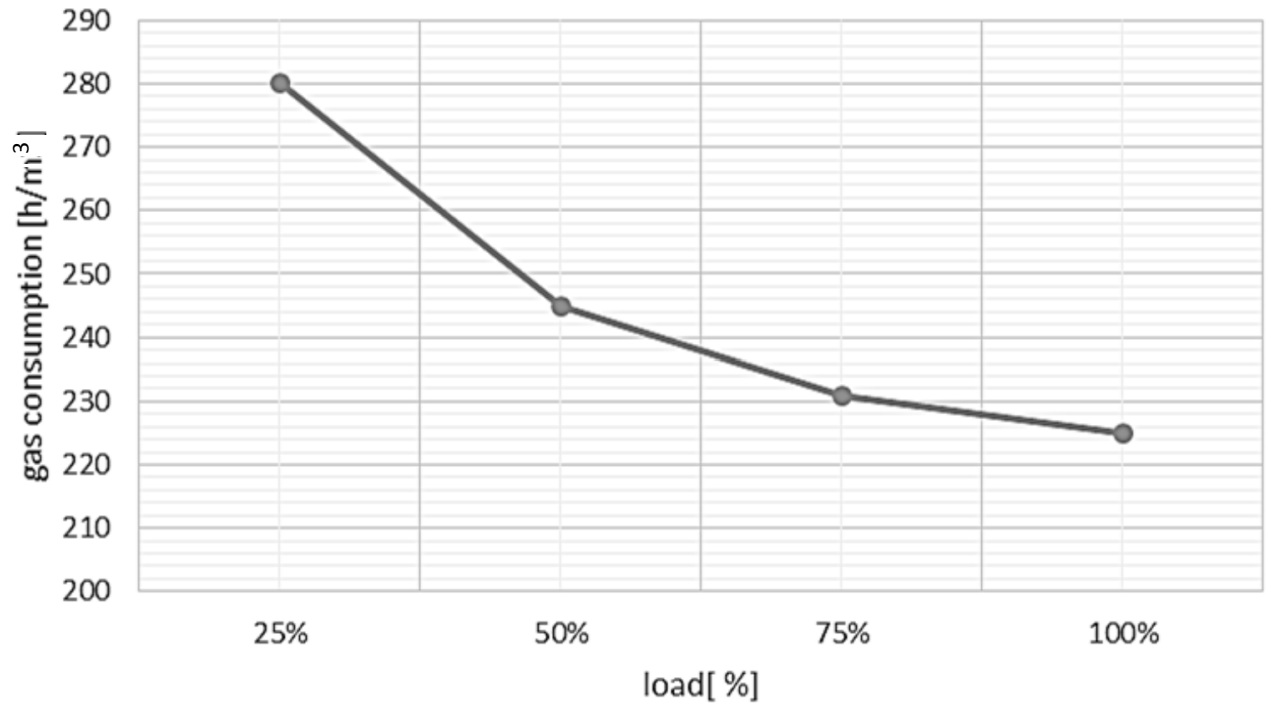

Fig. 4 Gas consumption according to the load Caterpillar team CG 260-16 Source: Based on [6].

\section{Topology}

II topology differs from I topology in the number and power of LNG-G generating sets. Three LNG-G generating sets with a power of $1.5 \mathrm{MW}$ were used in the system presented in Fig. 5.

This solution allows an independent power supply of ships from autonomous generating sets. This substantially increases the reliability of the system, and hence the problem described by I topology does not occur. LNG-G sets, just like in I topology, were installed in the main switchyard located far away from the quay. On the quay, there is only a device allowing the connection of a ship to STS system (davit with connecting rod).

LNG-G generating sets of a direct supply from the energy system with the use of frequency converters in comparison to the price of electricity produced in D-G sets was carried out. Averages prices of LNG and MDO, as well as electricity on land in Poland (January 2016) were assumed.
1. For I topology, the demand of LNG gas fuel to produce 1 MWh (assuming the LNG-G load aggregate $50 \%$ ) is 245 $\mathrm{Nm}^{3} / \mathrm{h}$. Taking into account that $1 \mathrm{Nm}^{3}=1.2 \mathrm{PLN}$, the price of $1 \mathrm{MWh}$ is $294 \mathrm{PLN}$.

2. For II topology, the demand of LNG gas fuel to produce $1 \mathrm{MWh}$ (assuming the LNG-G load aggregate 75\%) is 238 $\mathrm{Nm}^{3} / \mathrm{h}$. Taking into account that $1 \mathrm{Nm}^{3}=1.2 \mathrm{PLN}$, the price of $1 \mathrm{MWh}$ is $285 \mathrm{PLN}$.

3. For supply from the land energy system with the use of frequency converters, the price of $1 \mathrm{MWh}$ of energy is 280 PLN.

4. For supply from D-G marine generating sets, the consumption of MDO fuel for production of $1 \mathrm{MWh}$ is $300 \mathrm{l} / \mathrm{h}$ (assuming the D-G load aggregate of $40 \%$ ). With the price of $400 \$ /$ ton ( $\$=4 \mathrm{PLN}$ ), the price of $1 \mathrm{MWh}$ is 436 PLN. 


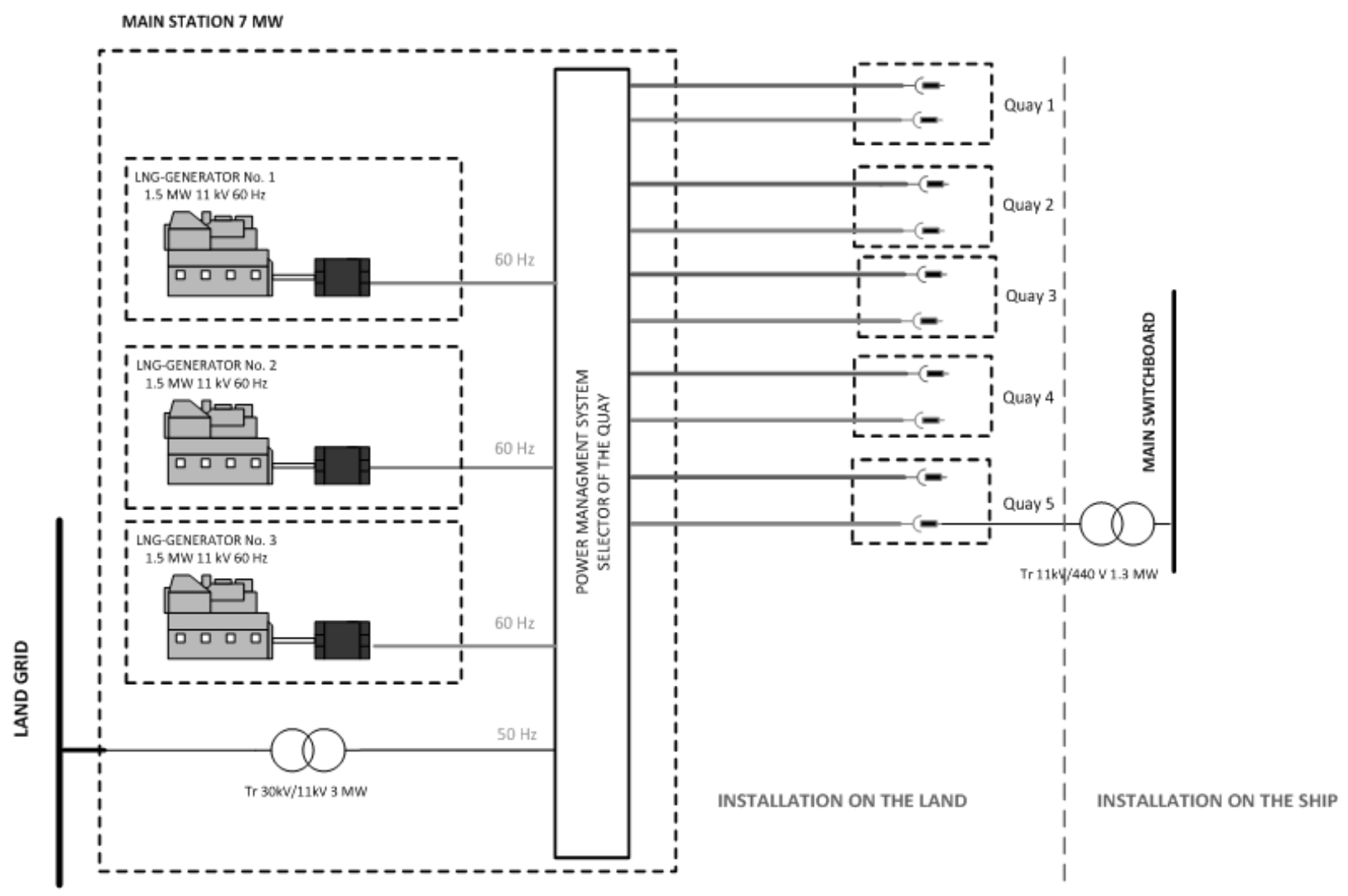

Fig. 5 Typology of STS system with the use of LNG - G 3x1.5 MW

Table 3

Advantages and disadvantages of different variants in STS system

\begin{tabular}{|c|c|c|}
\hline STS variant & Advantages & Disadvantages \\
\hline $\begin{array}{l}\text { Topology I } \\
\text { (with one } \\
\text { LNG-G set) }\end{array}$ & $\begin{array}{l}\text { Low price of } 1 \mathrm{MWh} \\
\text { Great effectiveness in the reduction of } \\
\text { exhaust emission. }\end{array}$ & $\begin{array}{l}\text { Large specific fuel consumption at low load of set } \\
\text { Very high maintenance cost of LNG-G set (approx. } 150 \text { thousand } \\
\text { PLN/year) } \\
\text { Safety system turns off the power during the state of emergency } \\
\text { High cost of investment } \\
\text { Construction of the regasification station }\end{array}$ \\
\hline $\begin{array}{l}\text { Topology II } \\
\text { (with three } \\
\text { LNG-G sets) }\end{array}$ & $\begin{array}{l}\text { Low price of } 1 \mathrm{MWh} \\
\text { Autonomy of LNG - generator - sets - } \\
\text { reliability of STS system } \\
\text { Possibility of modular construction } \\
\text { (container construction) } \\
\text { Great effectiveness in the reduction } \\
\text { of exhaust emission. }\end{array}$ & $\begin{array}{l}\text { Low efficiency of LNG-G } \\
\text { Very high maintenance cost of LNG-G set (approx. } 150 \text { thousand } \\
\text { PLN/year) } \\
\text { Safety system turns off the power during the state of emergency } \\
\text { Large Surface of the main distribution station } \\
\text { The highest investment cost along all STS variants } \\
\text { Construction of the regasification station }\end{array}$ \\
\hline $\begin{array}{l}\text { Supply from power } \\
\text { network (frequency } \\
\text { converter) }\end{array}$ & $\begin{array}{l}\text { Low price of } 1 \text { MWh } \\
\text { High efficiency of STS system } \\
\text { Low maintenance cost } \\
\text { Possibility of modular construction } \\
\text { (container construction) } \\
\text { Great effectiveness in the reduction } \\
\text { of exhaust emission } \\
\text { High reliability of STS system }\end{array}$ & $\begin{array}{l}\text { High cost of investment } \\
\text { Increase in } \mathrm{CO}_{2} \text { emission in }\end{array}$ \\
\hline
\end{tabular}

\section{CONCLUSIONS}

Table 3 summarizes all pros and cons of generating sets with LNG gas engines in STS system in relations to STS system powered by the energy network.

The summary presented in Table 3 shows that despite the obvious advantages of LNG-G generating sets in STS systems, currently, such systems will not be applied. It is primarily connected with large requirements about the operational safety (highly-qualified service). An example can be the port of Hamburg, where a pilot project of supplying passenger ships from barges was initiated. Becker Marine Systems and AIDA installed on these barges LNG-G 
generating sets. Barge with a length of $76.6 \mathrm{~m}$ has 5 generating sets from Caterpillar with a total power of $7.5 \mathrm{MW}$ [9]. Despite the positive tests of STS system with the use of LNG-G generating sets, in effect it was decided to build STS system based on supply from the national energy network with frequency converters in this port.

\section{REFERENCES}

[1] D. Tarnapowicz, T. Borkowski. Shore to Ship System: Alternative Power Supply of Ships in Ports, Szczecin: Scientific Publishing House of the Maritime University, 2014.

[2] D. Tarnapowicz, T. Borkowski. „"Shore to ship " system -an alternative electric power supply in port", in Journal of KONES, vol. 19(3), 2012, pp. 49-58.

[3] EU (2006/339/EC) COMMISSION RECOMMENDATION of 8 May 2006 On the promotion of shore-side electricity for use by ships at berth in Community ports (Text with EEA relevance).
[4] IEC/ISO/IEEE 80005-1. INTERNATIONAL STANDARD Utility connections in port - Part 1: High Voltage Shore Connection (HVSC) Systems - General requirements.

[5] R.R. Acosta. „Comparing Natural Gas and Diesel Generator Sets", in Power Engineering Magazine, vol. 119 (2), 2015.

[6] Technical data of CG170-16 and CG260-16 (2016) [Online]. Available: http://www.cat.com/en_US/ products

[7] Cryogas M\&T Poland S.A. LNG facilities - scheme (2016) [Online]. Available: http://www.cryogas.pl/ O_lng

[8] OPS calculation tool, version 05-08-2013 (2015) [Online]. Available: http://www.ops.wpci.nl/costs/cost -calculation/

[9] Becker Marine Systems, PRESS RELEASE NO. 7/2014.

dr inż. Dariusz Tarnapowicz

Maritime University of Szczecin, Faculty of Mechanical Engineering

Department of Marine Electrical Engineering and Electronics

ul. Wały Chrobrego 1-2, 70-500 Szczecin, POLAND

e-mail: d.tarnapowicz@am.szczecin.pl

Sergiej German-Galkin

University ITMO

Sablinskaja 14, 197101 Sankt Petersburg, RUSSIA

e-mail: ggsg@yandex.ru internetowej czasopisma.
The article in Polish language version available on the website of the journal 